\title{
A Comparative Study of Fiscal Federalism in Nigeria, the United States of America and the United Kingdom
}

\author{
Stanley C. Duruibe, M.Sc \\ L. E. Akujuobi, PhD \\ Chidinma Nwabeke, M.Sc \\ Sampson Ogoke, M.Sc \\ Kate Emenalom, M.Sc
}

Department of Financial Management Technology,

Federal University of Technology, Owerri, Imo State, Nigeria

Doi:10.19044/esj.2019.v15n28p197 URL:http://dx.doi.org/10.19044/esj.2019.v15n28p197

\begin{abstract}
The clamour for the adoption of 'true fiscal federalism' in Nigeria has been a burning issue in several quarters in the last three decades and has been documented in several articles, amongst which is the empirical study of Arowolo (2011:9). The United States of America (USA) which is the oldest federation in the world, and the United Kingdom-Nigeria's erstwhile colonial master - were compared alongside Nigeria using qualitative comparative research method. This paper shows that these three countries have a lot of fascinating resemblance and conflicting ideals. For instance, although these three systems of fiscal federalism assign more powers to the central government, the manner in which the exercise these powers varies from one country to the other. Notably, while the Federal system of government in Nigeria exercises control over the natural resources of the devolved units, the devolved unit in the USA maintain control over their natural resources and remit returns to the centre; and in the UK mineral resources such as oil, gas, coal, gold and silver are controlled by the state while others are owned privately. The study, therefore, recommends amongst others that Nigeria should take a clue from the USA and UK system of resource control and fiscal federalism in order to foster national cohesion and promote sustainable growth and development among the federating units.
\end{abstract}

Keywords: Fiscal Federalism, Nigeria, USA, UK

\section{Introduction}

Fiscal federalism, also known as fiscal decentralization or devolution, means the allocation of government resources and spending to the various tiers 
of government. It refers to the scope and structure of the tiers of governmental responsibilities and functions, and the allocation of resources among the tiers of government to carry out their various roles. Fiscal Federalism is, therefore, an offshoot of Federalism. Arowolo (2011) and Akindele and Olaopa, (2002) define Federalism as a political system in which state power is divided between the central or federal government, and regional governments (or provincial, state, territorial, cantonal, or other sub-unit governments) creating what is often called a federation. The study of Fiscal Federalism is very important as it evaluates which roles and instrument of government are best left in the domain of the central government, and which are best left in the hands of the sub-unit governments (Oates, 1999). According to Vincent (2001), the notion of federalism suggest that each level of government exercises its authority in an independent manner and should also have the right taxing ability to take advantage of its independent sources of revenue. Fiscal federalism requires that each level of government should be self-sufficient and be able to perform its functions without running to the other levels of government for financial succour (Wheare, 1963). Fiscal federalism is a very essential ingredient for the sustainability of any federation as it promotes fiscal devolution of authorities to the sub-national governments and gives them financial independence to raise revenue and spend such accordingly. Fiscal devolution implies assigning decision-making power to the lower levels of government instead of concentrating it at the centre. This process gives each level of government the discretion to take decisions and assign resources in areas of their importance within their areas of jurisdiction. Furthermore, the federating units should be allowed to act freely on issues within their own jurisdiction (Ewetan, 2011).

Fiscal federalism defines the fiscal interaction between the central government and the other lower levels of government, and this interaction among the branches of government in the federation is explained in terms of three main theories which are:

(a) The theory of fiscal relations: This theory explains the roles expected to be performed by each level of government in the fiscal allocation;

(b) The theory of interjurisdictional collaboration which indicates areas of shared responsibility by the central, state and local governments and;

(c) The theory of multijurisdictional community (Tella, 1999): Here, each jurisdiction such as the state or local government will provide those services that are only beneficial to people within its domain, thus, should use only such sources of finance such as Internally Generated Revenue (IGR) which will internalize costs incurred in the process of providing such services.

Having elaborated the theoretical background of fiscal federalism, efforts will be made to explore the manner in which fiscal federalism is practiced in 
selected countries such as Nigeria, USA and UK. Before moving further, it is imperative to state that the key subjects which have to be dealt with and, possibly, resolved in any sound system of fiscal federalism are: equity and accountability; complexity versus transparency; should taxes be centralised or devolved?; Should taxes be competitive?; and the impact of fiscal federalism on economic growth.

\section{Fiscal Federalism in Nigeria}

In Nigeria, the rise in the agitation for increased decentralization stems from the combination of people wanting to participate more in government, and the Federal government's failure to provide quality services (Aigbokhan, 1999; Oates, 1972; Tanzi, 1995; Chete, 1998). Soon after her independence, the military rule, characterised by a centralised system of government, dominated the subsequent years of Nigeria's political independence. This situation is the precursor of the present financial dominion enjoyed by the federal government over the thirty six states (36) states and federal capital territory, and seven hundred and seventy four (774) local governments' areas of the federation after the country return to civilian rule in 1999. That is why, in some quarters, the present system of democracy in Nigeria is often referred to as a residue of the military rule. This has generated dissatisfaction in the Nigerian federation. Thus the concern over the advancement of a practical fiscal federalism for Nigeria is well in place.

Although the agitation for true federalism in Nigeria is more pronounced in the last two decades ( i.e. at the dawn of the return to civilian rule in 1999 ) as documented by Arowolo (2011), it is pertinent to note that the origin of this campaign stems from the poor performance of the public sector since the first half of the 1980s. During this time Nigerians have contended with dwindling real incomes, high levels of unemployment and inflation, moribund education sector, decay in infrastructural facilities, insecurity challenges, distrust between the regions, abysmal national cohesion, just to mention a few. This abysmal performance of the public sector has averted the prospects for a sustainable national growth and development, which should be the basis of a practical fiscal federalism. The aforesaid socioeconomic malaises have catalysed to incessant struggle for change, and most recently the violence and tension in the Niger Delta Region of the country for resource control. Struggle for more devolved fiscal system by the lower levels of government have continued to be resisted by a leviathan ${ }^{1}$ federal government. Various commissions and committees have been set up in the past to address these issues. The recommendations of these committees will be briefly discussed below. 


\section{An Overview of the Recommendations of Various Fiscal Commissions in Nigeria}

$\rightarrow$ The duties of the early fiscal commissions was limited to allocating to the regional governments total "non-declared" revenue consisting of import and export duties and excise and company taxes which, under the Constitution, was determined by the central government.

$\rightarrow$ Phillipson Commission of 1946 recommended the use of derivation and even development as measure for distribution of revenue. Allocation of revenue followed this ratio: North, 46 per cent; west, 30 per cent and East, 24 per cent.

$\rightarrow$ The Hick-Phillipson Commission (1950) recommended need, derivation, independent revenue or fiscal autonomy and national interest as the measure for revenue allocation.

$\rightarrow$ Chicks Commission (1954) recommended derivation.

$\rightarrow$ Raisman Commission (1957) recommended a Distributable Pool Account (DPA) shared among the regions as follows: North, 40\%; East, 31\%; West, 24\% and Southern Cameroun, 5\%. When Southern Cameroun left the federation in 1961, the DPA was redistributed as follows: North, 42\%; East, $33 \%$ and West, 25\%. When the Mid-West region was created in 1963, the share due to the then Western Region was shared between it and the new region in the ratio of 3:1 (Ewetan, 2011, p. 98-99; Arowolo, 2011, p. 10).

$\rightarrow$ The Binns Commision (1964) advanced the principle of regional financial responsibility as against need and derivation. The revenue sharing formula was $42 \%$ to the north, $30 \%$ to the east, $20 \%$ to the west, and $8 \%$ to the mid-west.

$\rightarrow$ Decree No. 15 of 1967 was promulgated to share the revenue in the Distributable Pool Account (DPA) among the 12 newly created states in 1967 as follows: East Central, $17.5 \%$; Lagos, 2\%; Mid-West, $8 \%$; the six Northern states, 7\%; South Eastern region, $7.5 \%$; Rivers, $5 \%$; West, $18 \%$. The decree jettisoned all the basis of the previous revenue sharing formulae among the regions which include population, derivation and consumption among others (Ewetan 2011, p. 99).

$\rightarrow$ The Dina Commission (1969) recommended national minimum standards, balanced development in the allocation of the states' joint account and basic need (Arowolo 2011, p. 10).

$\rightarrow$ Other decrees that followed between 1970 and 1975 were designed to correct the irregularity of Decree No. 15 of 1967, by reallocating revenue to states on a more equitable basis (Ewetan 2011, p. 99).

$\rightarrow$ Aboyade Technical Committee (1977) recommended a national minimum standard for national integration: absorptive capacity, 21\%; fiscal efficiency, 15\%; equality of access to development opportunities, $25 \%$ and independent revenue effort, 18\%. Other criterion are 57\% to Federal 
Government; $30 \%$ to State Governments; $10 \%$ to Local Governments; and 3\% to a special fund (Arowolo 2011, p. 10 ).

$\rightarrow$ Okigbo Commission (1979) recommended percentages on principles: population, 40\%; equality, 40\%; social development, 15\%; and internal revenue effort, 5\%. Percentages for government: Federal, 53\%; States, 30\%; Local Governments, 10\%; and Special Fund, 7\% . (Ewetan 2011, p. 101; Arowolo 2011, p. 10).

$\rightarrow$ The 1984 Allocation of Revenue Act further modified the sharing formula as follows: federal, $50 \%$; states, 30\%; local governments, $15 \%$ and "others", that is, oil producing areas and ecological fund, 5\% (Ewetan 2011, p. 102).

$\rightarrow$ Danjuma Commission (1988) recommended the following sharing formula for government: Federal (50\%), States (30\%), Local Government (15\%), and Special Fund (5\%) (Arowolo 2011, p. 10).

$\rightarrow$ Under the current sharing formula: Federal, 52.68\%; the 36 states take $26.72 \%$, while the 774 local governments in the country take $20.60 \%$. Over time, this formula has generated controversies and remains a key factor in the clamour for true federalism and resource control. The provision in the 1999 constitution which vested the control of oil and natural gas in the government of the Federation, and not the state government or the individual, is also a contributory factor to the agitation for true federalism and resource control in Nigeria.

Also, experience has proved that revenue allocation portends the most difficult problem in Nigeria's fiscal federalism. A generally accepted formula has never been formulated, rather what has been presented overtime are measures of revenue allocation which are not based on rational consideration, but some primitive consideration. As a result of this, the revenue allocation formulae only impaired the ability of the states to generate revenue, as states solely depend on the monthly allocation from the federation account. The consequence of this revenue allocation dependence is that it limits the ability of states and local governments to provide public goods needed to sustain good governance. The problem is that, under the current formula, the federal government takes the largest share of the accumulated revenue, thereby leaving state and local governments with small shares which do not match the designated functions they are meant to carry-out (Ewetan O. O. 2012).

\section{Fiscal Federalism in the United States of America.}

\section{The Evolution of Fiscal Federalism in the United States of America}

Following the failure of its Confederal form of government in 1781, the United States of America (USA) adopted the federal form of government in 1789 thereby becoming the first modern federation in the world. Initially, the federation comprises of 13 states, but through its expansionism policy over 
the years, the federation has evolved into a federation of 50 states, a federal district (Washington DC, the capital city of the United States), 5 major territories, various minor Islands, over 130 Native American domestic dependent nations, and numerous municipal governments. Despite the experience of series of political upheavals and a civil war in its first century of existence, The United States of America still upholds the tenets of the 1789 federal constitution which make the federation the oldest in the world ("United States of America", n.d.). Thus any comparative study of fiscal federalism will use United States' experience as a baseline.

The 1789 federal constitution of the USA was adopted with the following goals: First, it aims to correct the anomalies in the Articles of Confederation, thus, giving the federal government more capacity to coordinate the activities of the state government. The new federal structure instituted by the 1789 constitution was saddled with more powers which include the administering of international and interstate trade and to avert the states from competing and coming into conflicts in these areas. Second, the constitution aims to limit the powers of the new federal government through a set of checks and balances ("United States of America", n.d.) Thus, in comparative terms, the United States is moderately non-centralized. Each state has its own constitution grounded in republican principles and also possesses some rights and powers under the United States constitution which serves as the supreme law of the Federation. The rights and powers of the states include: running elections ( states regulate most aspects of elections in the USA, including primaries, the eligibility of voters, running of state electoral college etc); creating local governments; ratifying constitutional amendments; administering the greater part of the criminal law and Justice; jurisdiction over civil law; power to levy taxes and other fees; controlling most domestic functions other than those associated with the regulation of the economy, including education, health, environmental protection and social services and controlling intrastate commerce. Each state and their residents have representatives in the federal congress consisting of the Senate and House of Representative (Two senators from each state for six years term and House of Representatives nominated according to population). There is a clear separation of power between the executive, legislative and judicial arm of government that exist in the federal and state government level ("Federal Government of the United States", n.d.).

The endorsement of the $16^{\text {th }}$ and $17^{\text {th }}$ amendments in 1913 removed some limitations on the powers of the Federal government. These amendments gave the federal government unrestricted taxing powers and stipulated that congressmen were to be elected in a general election by popular votes instead of selected by state legislatures. The federal government's powers and rights include levying taxes, provided it does not discriminate among states; the 
power to control foreign and interstate commerce; the absolute power to discuss the USA treaties and conduct foreign relations; administering national defence and the control of the armed forces; and the prerogative to handle crimes against the United States (Constitutional Amendments: The Bill of Rights 2018). It is noteworthy that the United States' Constitution makes no reference to local governments. Local governments' administration is a subject of the various state constitutions. Thus, the nature of the relationship between state and local governments, and among local governments, varies from one state to another.

Over these years, the powers of Washington over public and private life have been on the rise. Washington has exerted regulations bordering on clean air and water, access for the disabled and several other social goals. They have also come up with several unfunded federal mandates ${ }^{2}$ on states and local governments which tend to be burdensome on these units. The National Conference of State Legislatures (NCSL) recognized 192 unfunded mandates on the states which include: Medicaid, the Clean Water Act, the Clean Air Act, the Resource Conservation and Recovery Act, regulations governing the use of underground storage tanks, the Safe Drinking Water Act, requirements to remove asbestos and lead paints from schools and other areas, the Endangered Species Act, the Americans Living with Disabilities Act and the Fair Labour Standards Act. The U.S.A Conference of Mayors and Price Waterhouse appraise the cost of these mandates between 1994 and 1998 (with exception of Medicaid) on 314 cities at $\$ 54$ billion, or the equivalent of $11.7 \%$ of all local taxes (Robert S. Stein, 1994).

\section{Revenue and Expenditure Allocation and Provisions Related to Intergovernmental Transfers in the USA}

Revenue and Expenditure Allocation. The Constitution of the USA invests enormous discretionary power on the federal government to raise revenue. However, collecting tax revenue is not the exclusive right of the federal government as states also have right to raise revenue through taxes and control the local government taxing rights. Both levels of government can exploit the major revenue sources such as personal income tax, company tax and selective sales taxes. The U.S.A has a decentralised tax administration system, with each order of government having its own administrative system to collect the taxes it imposes (Watts, 1999).

For natural resources control in the context of fiscal federalism in the USA, data from the Office of Natural Resources Revenue, Information and Data Management of the U.S Department of Interior shows that oil and natural gas are owned by the state and private individuals who remit taxes to the federal government. 
In terms of expenditure allocation, there is no difference between the law-making and spending powers of the federal and state governments. The two levels of government have a close connection in the areas of spending that falls under the concurrent prerogative. More so part of the state and local spending is from the federal government. In spite of the inclination for state expenditure responsibilities to grow over time, the federal government still commands a dominant role in public spending in the United States. While most of state and local expenditure responsibilities are in areas of high growth such as education and health care, the federal government spends heavily in many high growth areas either concurrently with the states (e.g. health care) or exclusively in the areas of social security programs and national defence (Ronald and Marianne 2000).

\section{Intergovernmental Transfers in the USA}

The USA constitution does not recognize intergovernmental transfers. Therefore, arrangements that provides for vertical transfers or equalization plans are rarely available. In the same vein, the constitution does not stipulate percentage of federal taxes that should go to state governments. However, only a few federal taxes such as airport and fuel tax have been dedicated to state and local government to finance the transportation system (USA Constitution, Bill of Rights and all Amendments).

This does not mean to say that intergovernmental transfer does not exist in the USA as nowhere in the constitution of the USA was it prohibited. Over the years, due to the greater revenue-raising and spending power of the federal government, states and local governments have relied heavily on transfers from the Federal government to carryout there financial obligations. Federal transfers have been used to cover a broad aspect of government functions such as health, social services, education, environmental protection, transportation and regional development. A considerable fraction of federal grants are passed on from state governments to local governments. Moreover, state governments make available some of their own-sourced grants to local governments. These transfers come in the form of conditional grants which stipulates what the grant is meant to achieve such as the nationally defined policies of the federal government, or to help the states in the area of redistributive policies among others (Ronald and Marianne 2000).

According to Ronald (1999), two variants of conditional transfers exist: the block transfers which have less restriction on how these funds will be used by the state governments or local government and the categorical transfers that make available financial assistance for some specific programs and its fund utilization is restricted to programs assigned. Formula-based categorical transfers distribute wealth to state and local governments based on legislative or administrative standard set by the federal government. Formula 
transfers consist of open-ended grants with matching requirements, and closed-ended matching and non-matching grants. Project grant, another variant of categorical transfer, is given discriminatory to states and local governments on the basis of application.

There has been a serious worry in the U.S.A writings on fiscal federalism in the context of the principle of financial responsibility. Political accountability demands that the level of government that raises the revenue should be the level of government that determines how it should be spent. In a parliamentary system, accountability for funds transferred from one level of government to the other is promoted as the executive that receives the funds is directly responsible to a legislature and by extension to an electorate. This is not the case in the USA system as the executive arm of government does not have such direct accountability to the legislature and electorate. Thus, the conditional transfer is used to recompense for this lack of accountability at the state level. Since it is the federal government that raises the funds being transferred, it demands that states should be accountable for those funds by stipulating the conditions on how the state or local government should spend them. Thus, presently almost all federal grants to state and local governments are conditional in nature. This kind of arrangement weakens state autonomy as states do not have the discretion to spend these funds on their priority areas other than that stipulated by the federal government. One of the advantages of using conditional grants is the inherent higher level of transparency than is found in some other federations (Ronald and Marianne 2000).

\section{Fiscal Federalism in the United Kingdom Introduction}

The United Kingdom (UK), which comprises of England, Scotland, Wales and Northern Ireland, is a parliamentary democracy with a king or a queen as the head of state and a prime minister elected every five years duration as the head of government. The people also vote in their members of parliaments (MPs) to represent them. The prime minister chooses his ministers who form the Cabinet. The UK practices a unitary system of government where power is concentrated at the centre; although some powers have been recently devolved to Scotland, Wales and Northern Ireland to make certain government policies.

After the referendums in Scotland and Wales in 1997, and in both parts of Ireland in 1998, the UK parliament transferred some powers and authorities to the national assemblies. This situation gave birth to the Scottish Parliament, National Assembly for Wales, and the Northern Ireland Assembly in 1999. The Scottish Government, (previously known as the Scottish Executive) is the devolved government of Scotland. The Scottish Government, which is answerable to the Scottish Parliament, develops and executes policies in the 
areas of health, justice, education, transport and rural affairs. The National Assembly for Wales is the representative organ which passes legislation on devolved matters. The Welsh Assembly Government, which is answerable to the National Assembly for Wales, develops and implements policies in areas such as health, education, culture, environmental issues, economic development and transport. The Northern Ireland Executive is the devolved government of Northern Ireland. It legislates on areas of agriculture and rural development, public safety, social services, arts, culture, health and social and economic matters. The Northern Ireland Assembly, on the other hand, debates and makes laws, and inspects and reaches decision on the Northern Ireland government departments. They also deliberate on proposals for new laws presented to it by the Northern Ireland Executive Committee ("National Archive of the UK Government", 2012).

\section{An Overview of Fiscal Federalism in the UK}

Fiscal federalism in the UK is primarily concerned with the allocation of powers and obligations between the UK government and the devolved national governments of Wales, Northern Ireland, and Scotland. According to Ben Lockwood (2013), the system of governance in the UK is one of the most centralized systems of government in the developed world. Thus local governments have a very limited power in the areas of tax management and expenditure administration which inhibit their policy direction. Local governments have only one local tax which is the residential property tax, also known as the council tax, which they have jurisdiction over the setting of the rate. Local business rates were eradicated in 1990 and an even business rate was introduced. The revenues generated from this even business rates are reallocated to local governments as part of the formula-based grant. Thus, suffice to say that local authority taxes ( i.e. council taxes and business rates) are devolved in the UK. This system of operations in the UK is quite different from that obtainable in many other countries, where regional governments have a lot of diverse major taxes under their jurisdiction.

Ben Lockwood (2013) further asserts that local governments depend heavily on grants from central government. In 2011 these together constituted $70.5 \%$ of council revenues. This makes UK local government one of the most reliant on central government grants among the countries in the Organisation for Economic Co-operation and Development (OECD). More so, a central government power to limit local government spending which is known as 'rate-capping', have been on the statute books since the Rates Act 1984, and was also adopted in the 1992 Local Government Finance Act. The Localism Act of 2011 replaced the rate capping regime with a proposition for increases in local government taxation on the condition that a referendum will be conducted if the increase is perceived as being too much 
In the aspect of resource control under the UK context, the UK Centre for Sustainable Mineral Development documents that ownership and control of oil, gas, coal, gold and silver in the UK is exclusively vested in the state. Apart from the aforementioned minerals, the state does not own mineral rights in the UK. In general, there is private ownership of mineral resources in the UK and any information on mineral rights can be obtained from the Land Registry, together with details of land surface ownership.

Michael (2015) contends that the UK government takes responsibility for all national policies that have not been devolved to the national government, and these responsibilities include: defence, social security, foreign affairs, trade and macro-economic management. The UK government also takes responsibilities for government policy in England. Moreover, the UK parliament can make legislations for any part of the UK with the agreement of the devolved government on areas of devolved matters.

\section{Public Expenditure Framework in the United Kingdom}

Over the years, a public expenditure method known as the Barnett Formula (named after Joel Barnett who initiated it in 1978, while chief Secretary to the Treasury, as a temporary remedy to little cabinet disagreements in the build-up to planned political devolution in 1979) has been used by the UK treasury to automatically adjust the amounts of public expenditure allocated to Northern Ireland, Wales and Scotland to reflect changes in expenditure allocated to public services in England, England and Wales or Great Britain, as the case may be. The formula only pertains to expenditure on matters for which the devolved administrations are responsible. The basic principle of this formula is that any rise or fall in expenditure in England will automatically lead to an equivalent rise or fall in expenditure allocated to the devolved governments in Scotland, Wales and Northern Ireland. This formula does not apply to all expenditures, but is the most likely option if no other decision is reached. The expenditure is allocated as a whole thereby availing each devolved administration the opportunity to allocate these funds as it deems fit. In aspects where the central government department funding covers England only, such as in the areas of health and education, the corresponding funding to the devolved governments comprise a baseline plus increases based on the increases in public spending in England in similar programmes, applied in comparison to existing population. This Formula has no legal backing or democratic validation as it is just an ordinary convention that can be indiscriminately changed by the treasury. In 2009, the House of Lords Selected Committee on the Barnett Formula jettisoned the formula and recommended the introduction of a new system which allocates resources to the devolved units on the basis of their relative needs. In the event of the Scottish independence referendum of September 2014, the Barnett 
formula received extensive attention amid concerns that in a last-minute government effort to lure voters to vote against Scottish independence, pledged to allocate more public spending to Scotland ("Barnett Formula", n.d., para. 1-4).

A number of the conflicts and apprehension witnessed on both sides of the English and Scottish frontier stems from the move towards significant fiscal federalism in one part of the UK. Some political pundits and public sector analysts in the UK hold the view that if the Labour government in UK had adopted federal structure for the UK as a whole prior to 2010, the momentum of the call for Scottish independence would not have taken an overwhelming dimension.

\section{Summary, Conclusion, Recommendations and Lessons for Nigeria}

So far, this study explored fiscal federalism in Nigeria, USA and the UK - bringing insights into some of the highpoints in fiscal federalism as practiced by these various nations. In comparative terms, these three countries have a lot of interesting similarities and divergent ideals. For instance, the three systems of fiscal federalism assigns more powers to the central government, although the manner in which the exercise these powers varies from one country to the other. While the United States is moderately noncentralized, the system of governance in the UK is one of the most centralized systems of government in the developed world. Nigeria's fiscal system, on the other hand, is moderately centralised with the leviathan federal government having an overwhelming control over the economy.

In the USA, each state owns a constitution and also draws some rights and powers under the United States constitution which serves as the supreme law of the Federation. Among the rights and powers of the states are running most aspects of elections in the USA, including primaries, the eligibility of voters, running of state electoral college; creating local governments; ratifying constitutional amendments; administering the greater part of the criminal law and Justice; jurisdiction over civil law; power to levy taxes and other fees; controlling most domestic functions other than those associated with the regulation of the economy, including education, health, environmental protection and social services; and controlling intrastate commerce. This is not the case in Nigeria were the federal government have an overwhelming control over state activities and resources. In fiscal terms, majority of federally raised revenue flow into the Federations Account which is in turn share according to a predetermined percentage. The federal government takes the greatest share from this accumulated revenue in the Federation Account, thus leaving state and local governments with small shares which are not enough to carry out their designated function. In the UK, on the other hand, a public expenditure mechanism known as the Barnett Formula has been used by the UK treasury 
to automatically adjust the amounts of public expenditure allocated to Northern Ireland, Wales and Scotland to reflect changes in expenditure allocated to public services in England, England and Wales or Great Britain, as the case may be. The formula only pertains to expenditure on matters for which the devolved administrations are responsible. The basic principle of this formula is that any rise or fall in expenditure in England will automatically lead to an equivalent rise or fall in expenditure allocated to the devolved governments in Scotland, Wales and Northern Ireland. This system of revenue allocation tends to be fairly equitable than the revenue allocation formulae in Nigeria which are not based on rational consideration, but some primitive consideration.

Under the United States' fiscal federalism, Local governments' administration is a subject of the various state constitutions. The Federal constitution makes no mention of local government. Thus, the nature of the relationship between state and local governments, and among local governments, varies from one state to another. One major advantage of this setting is that it makes government very closer to the people in its true sense. In Nigeria, local governments are recognized by the federal constitution as the third tier of government. The bulk of their revenue comes from the statutory allocation from the federal government. This practice is similar to that obtainable in the UK were local governments depend heavily on grants from central government to run their day-to-day activity. Local governments in the UK have a very limited power in the areas of tax management and expenditure administration which inhibit their policy direction. This contrasts with Nigeria and USA where local governments have considerable taxes under their jurisdiction.

Furthermore, some forms of conditional transfer exist in Nigeria. A typical example is the Universal Basic Education (UBEC), where the federal government makes $2 \%$ of its statutory allocation to states. The USA fiscal system does not recognize intergovernmental transfers. In the same vein, it does not stipulate percentage of federal taxes that should go to state governments. That does not mean to say that intergovernmental transfers do not exist in the USA as nowhere in the constitution was it banned. As a matter of fact, due to the greater revenue-raising and spending power of the US federal government, states and local governments rely greatly on transfers from the Federal government to carryout there financial obligations. A considerable fraction of federal grants are passed on from state governments to local governments as conditional grants which stipulate what the grants should be used for. This kind of arrangement weakens state autonomy as states do not have the discretion to spend these funds on their priority areas other than that stipulated by the federal government. This contrast with Nigeria and 
UK where the regional governments have the discretion to spend the grants from the centre how it deems fit.

In Nigeria, the legal right to own and control natural resources, including oil and gas, resides with the federal government, whereas in the USA onshore resources ownership normally resides with the states. In the UK, apart from oil, gas, coal, silver and gold which are owned by the central government, all other mineral resources are privately owned. This case of the control of natural resources being vested in the hands of the federal government of Nigeria is the precursor of the agitation for resource control in the Niger Delta region of Nigeria. It is the considered opinion of this study that states should control their natural resources and use same to develop their regions while the remit returns to the Federal government. This study does not consider it appropriate a situation where resources emanating from one state or region are used to develop another state or region at the detriment of the state that owns the resources. This scenario tends to make some states unproductive and, thus, make them rely on others states for succour and means of their survival. In Nigeria, states run to Abuja monthly to grab their share of the national wealth even when some of these states contribute little or nothing to the national wealth. One notable, as well as worrisome, case at hand is where tax revenues raised from sales of alcohol from liberal states that permit the sale and intake of alcohol is shared among all states - together with some states that prohibit the sale and intake of alcohol due to religious ideology.

Thus, this study is of the opinion that resource control will encourage every state to improve on their mineral deposits, revenue raising abilities and productive capacity. This study draws its argument from the USA and UK system of natural resource control where state and private ownership of natural resources exist and returns remitted to the central government. This system encourages healthy competition for exploration and development of natural resources among states and regions in the federation which in turn culminate to even and sustainable economic growth and development. Therefore, it is suggestive that Nigeria should take a clue from the USA and UK system of resource control to foster national cohesion and promote sustainable growth and development.

\section{Endnotes}

${ }^{\mathbf{1}}$ Leviathan model was first developed by Geoffrey Brennan and James Buchanan in their book, "The Power of Tax" published in 1980. In this model, government is presumed to act as a monopolist that maximises tax revenue. The theorised that government tries to get control of as much of the economy as possible.

${ }^{2}$ Federal mandates are requirements set out by the Federal government through legislation, executive order, or judicial fiat which mandate state and 
local governments to embark on a number of programs or provide some services at their own cost.

\section{References:}

1. Arowolo, D. (2011). Fiscal federalism in Nigeria: Theory and dimensions. Afro Asian Journal of Social Sciences, 2(22), 1-22.

2. Aigbokhan, B.E. (1999). Fiscal federalism and economic growth in Nigeria, in Fiscal Federalism and Nigeria's Economic Development 1999 proceedings of the annual conference of the Nigerian Economic Society, Nigerian Economic Society, Ibadan, pp. 333-352.

3. Akindele, S.T. \& Olaopa, K. (2002). Fiscal federalism and local government finance in Nigeria: an examination of revenue, rights and fiscal jurisdiction. In Omotoso, F. (Ed.), Contemporary Issues in Public Administration, Bolabay Publications, 46-64.

4. Barnett Formula (n.d.). In Wikipedia. Retrieved March 15, 2019, from https://en.m.wikipedia.org/wiki/Barnett_formula

5. Ben Lockwood (2013). Fiscal Federalism in the UK: How Free is Local Government? Chatham House, United Kingdom.

6. Chete, L.N. (1998). Fiscal decentralization and macroeconomic management in Nigeria. Journal of Economic Management, 6 (1), 91114.

7. Constitution of the United States of America (2018). Bill of Rights and all Amendments. Retrieved September 3, 2019 from https://constitutionus.com

8. Centre for Sustainable Mineral Development (n.d.). Legislation and Policy: Mineral Ownership. Retrieved January 6, 2019, from www.bgs.ac.uk/mineralsuk/planning/legislation/mineralOwnership.ht $\mathrm{ml}$

9. Dee J. Kelly Law Library (2018). United States ConstitutionConstitutional Amendments: Amendments 11-27. Retrieved April 10, 2019, from https://law.tamu.libguides.com/usconstitution

10. Ewetan, O.O. (2011). Fiscal federalism and macroeconomic performance in Nigeria. Unpublished $\mathrm{PhD}$ thesis, Covenant University, Ota.

11. Ewetan O. O. (2012). Fiscal federalism in Nigeria: Theory and Practice. International Journal of Development and Sustainability, 1(3), 1075-1087.

12. Federal Government of the United States. (n.d.). In Wikipedia. Retrieved March 12, 2019, from https://en.m.wikipedia.org/wiki/Federal_government_of_the_United_ States 
13. Geoffrey B., and James, M. Buchanan (1980). The Power to Tax: Analytic Foundation of a Fiscal Constitution. Cambridge University Press, New York.

14. Michael, L., (2015). Fiscal Federalism in the UK. The Federal Trust for Education and Research, 1-28.

15. U.S Department of Interior (n.d.). A Publication of Office of Natural Resources Revenue, Information, and Data Management: Natural Resources Revenue Data. Retrieved December 15, 2018, from https://revenuedata.doi.gov/how-it-work/ownership

16. Oates, W.E. (1972). Fiscal Federalism. Harcourt Brace Jovanovich, New York, NY.

17. Overview of the UK System of Government. Archived on 3 Oct 2012. $\begin{array}{llll}\text { Retrieved } & \text { May } & 17 & \text { 2019, from }\end{array}$ www.webarchive.nationalarchives.gov.uk.

18. Oates, W.E. (1999). An essay on fiscal federalism. Journal of Economic Literature, JSTOR, 37(3), 1120-49.

19. Ronald L. W., \& Marianne V. (2000). Fiscal Federalism in the United States.

20. Ronald L.W.(1999). Comparing Federal Systems. 2nd ed.; Montreal and Kingston: McGill-Queen's University Press, 21.

21. Robert S.S. (1994). Decentralizing American Government: People, Politicians Seek Power Closer to Home. Investors Business Daily, A1.

22. Tella, S.A. (1999). Promoting states economic independence through financial market cooperation. In Fiscal Federalism and Nigeria's Economic Development, 1999 proceedings of the Nigerian Economic Society, Nigerian Economic Society, Ibadan, 171-187.

23. Tanzi, V. (1995). Fiscal federalism and decentralization: A review of some efficiency and macroeconomic aspects. In Bruno, M. and Pleskovic, B. (Eds.), Annual World Bank Conference on Development Economics, the World Bank, 317-322.

24. United States of America. (n.d.). In Wikipedia. Retrieved March 9, 2019, from https://en.m.wikipedia.org/wiki/United_States.

25. Vincent, O.O. (2001). Fiscal Federalism: The Nigerian Experience. Fourth Public Lecture, the Nigerian Economic Society. Ibadan.

26. Wheare, K.C. (1963). Federal Government, 4th edition, Oxford

27. Watts, Ronald L.(1999). The Spending Power in Federal Systems: A comparative study. Kingston Queen's University Institute of Intergovernmental Relations. 